\title{
Radical Dewey: Deweyan Pedagogy IN MeXico, 1915-1923
}

\author{
Victor J. Rodriguez
}

\section{ABSTRACT}

From 1915 to 1923, the pedagogy of John Dewey became an important pillar of anarchist and socialist projects of education in Mexico. These radical experiments were based on the belief in an open-ended world amenable to the intervention of a new subject of modernity whose unconstrained operations created rather than disrupted social order. Ironically, these experiments paved the way for the appropriation of Dewey by an emerging national state that posited homogenization, the eradication of difference, and the displacement of Native and religious worlds as necessary to create a shared set of values necessary for the operations of this subject.

\section{INTRODUCTION}

This paper focuses on the uses of Dewey's ideas in Mexico before his appropriation by the Mexican revolutionary government in 1923. During the early 20th century, anarchists, socialists, and teacher advocates of progressive education in Mexico invoked the name of John Dewey as an important pillar for a vision of a modern Mexico. Deweyan ideas circulated among these radical pedagogues, sprouting in urban centers such as Mérida in Yucatán province, or in poor barrios of México City, where pockets of urban radicalism emerged concurrently without the necessity of concerted action. Subsequently, self-professed disciples of Dewey founded the journal Educación identifying Dewey as a member of the journal's board of editors. Few if any historians have paid adequate attention to any of these uses of Deweyan education in Mexico during this time. ${ }^{1}$ This neglect may be due in part to the fact that most Mexican experiments with foreign education during that time withered or were successfully co-opted by the national state. With scattered sources to encourage research and a common assumption that Dewey was no more than a name uttered on behalf of idealistic, quixotic, and perhaps contradictory experiments, scholars have neglected the intellectual foundations of the experiments that preceded the state project of the escuelas activas, the name given to the Mexican revolutionary experiment with Deweyan schools in the mid-1920s. Given this silence, the established interpretation of the role of Deweyan thought in Mexico 
maintains that the popularity of Dewey's ideas should be understood purely in terms of its utility for a nationalist state desiring to establish social control over its population in order to consolidate capitalist relations. ${ }^{2}$

The importance of these early projects and discourses on Dewey in Mexico resides in the various ways they illuminate the way Deweyan thought became embedded within the progressive nationalist Mexican imagination. ${ }^{3}$ They explain why Dewey's import for Mexican intellectuals shifted from experiments that aimed for social justice and democratic life to ones that prioritized Deweyan education as an avenue for making Mexicans modern individuals, that is, self-conscious, practical, entrepreneurial, and secular. Thus Dewey became "Americanized," understood as a key to unlocking the productive potential of the American. They illuminate how tensions plagued the uses and invocations of Dewey as the process to create a common purpose in the classroom and provide it with an underlying unity eventually contradicted the means-ends philosophy that animated the democratic and egalitarian aspirations of Dewey's pedagogy. These projects held in common that the diversity of Mexico's life-worlds constituted essentially a roadblock to modernity, ${ }^{4}$ an expression of the concern with the resolution of what Mexican social scientist, Andrés Molina Enríquez, denominated Mexico's "Great National Problems," oftentimes conceived in racial terms: how the plurality of Indian worlds and the miscegenated character of the Mexican constituted an encumbrance to progress. ${ }^{5}$

In this monograph, I intend first to be descriptive, aiming to provide a brief survey of these non-state Dewey projects. I begin by focusing on the intellectual foundations of the escuelas racionalistas or rationalist schools, which were experiments in anarchist education established during the first decades of the $20^{\text {th }}$ century. I then proceed to analyze the thought and aspirations behind the escuelas activas movement, focusing on the writings (and projects) of Eulalia Guzmán, discourses and debates among Mexican teachers, and finally, the emergence of the journal $E d u$ cación, where Dewey's ideas gained supremacy among key Mexican pedagogues. I conclude by identifying correspondences between American progressivism, including Dewey's own ideas, and those of his Mexican interpreters. I have chosen these sources selectively from among the various progressive voices where John Dewey figured prominently.

Analytically, this essay aims to re-consider an important problem in the translation of Dewey's ideas in the world. Recent historical work on Dewey's influence in the early $20^{\text {th }}$ century has shown how Dewey's followers consistently debated and oftentimes rejected his warning that democracy could only be begotten through democratic means. These scholars have also identified contradictions in Dewey's own thought. David C. Engerman has noted how Dewey's “endorsement of Soviet practices in Russia" was coupled with his rejection of Soviet means "for his own country." Jessica Wang, although a more sympathetic observer of Dewey in China, notes tensions between Dewey's fondness for preserving the rich plurali- 
ties of the Chinese village world and his simultaneous desire for a common foundation that could secure the necessary political basis for the industrialization and secularization of China. ${ }^{7}$ The collective of writers in Inventing the Modern Self and John Dewey have similarly uncovered contradictions between means and ends in worldwide projects to create individuals as agents of change. ${ }^{8}$

The Mexican cases covered in this essay preceded these engagements with Dewey and reproduced some of these contradictions, suggesting that tensions stemmed not simply from misinterpretations or misappropriations of Dewey, but also from a more complex reading of American progressivism in general and pragmatism in particular. If we could extend to progressivism Cornell West's characterization of pragmatism as "a continuous cultural commentary or set of interpretations that attempt to explain America to itself," then Mexican readings of Dewey and American progressivism involved an interpretation of that interpretation and of its ambiguities. ${ }^{9}$

\section{The Anarchists’ escuelas Racionalistas OR RATIONAlist SchOOLS}

Anarchists implemented in Mérida, in the state of Yucatán, very important educational projects led by José de la Luz Mena, a Spanish immigrant who established the first anarchists schools in 1917 in Chuminópolis. They were inspired by the pedagogy of Francisco Ferrer i Guardia, a working-class radical executed by the Spanish government in $1909 . .^{10}$ The schools were called rationalists or racionalistas because of their profession of faith in the rational nature of man and the universal applicability of science, whose truths were deemed universal and objective. ${ }^{11}$ "Science," Ferrer exclaimed in his book, "is the sole mistress of our life". ${ }^{12}$ Dewey's pedagogy had impacted anarchist education in Europe before it moved to the United States and Mexico in the late 19th century. ${ }^{13}$ Shortly after Spanish exiles and Mexican anarchists formed the first anarchist organizations in the city of Mexico, the writings of Ferrer, collected in the volume The Modern School and Dewey's works, such as The School and Society and How To Think, began to circulate among leftist intellectuals along with Peter Kroptokin's Mutual Aid: A Factor of Evolution and The Conquest of Bread, Mikhail Bakunin's God and the State, and Pierre-Joseph Proudhon's What is Property? Or an Inquiry into the Principle of Right and Government. ${ }^{14}$ Mexican labor unions joined public readings of these books as they celebrated in 1914 the fifth year anniversary of Ferrer's execution. ${ }^{15}$

The anarchist project in Mexico was not necessarily intended to be purely a conversation with its American socialist and anarchist counterparts, but instead aspired to be part of a more universal project of human liberation. Mexicans never claimed that their schools were purely Deweyan either, yet they invoked Dewey as a model for a very important dimension of their educational mission: the power of 


\section{Victor J. RODRIGUEZ}

the school to re-create within itself a model for the future community. The document that set the legal foundations of the school, for example, identified two Deweyan postulates as bases of anarchist pedagogy: that all schools had to reflect the "principles of life" and that the school had to become a "society in miniature" with no "antagonism" in relation to the larger society. ${ }^{16}$ Organizing learning around agricultural and industrial work, the production of crafts, and the sale of manufactured articles in the market, inserted production at the center of learning in ways analogous to Deweyan schools at Chicago. ${ }^{17}$

For these anarchists, the vision of a school as a "society in miniature" constituted the most attractive Deweyan idea because its implementation promised to liberate the mind of the student from the "artificial" order created in Mexico by Catholicism, which prevented individuals from relating to life and understanding its real logic. ${ }^{18}$ It was a form of alienation that the school could remedy by creating within it a "society in miniature" that would reflect the "principles of life," in other words, that would reveal to the student in the classroom how the real world worked and how it was produced so the student could name that world as his own. Removing religious mysticism would establish in the child conceptual avenues to a world deemed transparent and available to human knowledge and transformation. In this sense, they found congruence between Dewey's thought and Ferrer's mission to create purely secular schools removed from the influence of the church. Rationalist schools promoted this new orientation to life by encouraging students to publish their own newspapers, to read publications from different parts of the world, and to engage in the exploration of the natural world that surrounded them. They introduced student savings banks, a Republic of Workers, American Boy Scouts clubs, cooperatives, and other institutions in an effort to create a production cycle within the school that would reflect how life works in reality. ${ }^{19}$ Thus anarchists proposed to create within the school a social order they identified as "natural," by which they meant democratic, secular, egalitarian, and objectively real.

Anarchists moved beyond Dewey by construing this natural world as one characterized by freedom from any mediating form of authority. All forms of association that replicated or re-produced hierarchical relations were to be abolished. de la Luz Mena advocated the importation of a great number of pedagogical ideas inspired by American progressive education for that purpose, such as student clubs, pupil participation in school administration, and student associations, in order to provide the perfect environment for a fully democratized form of social inquiry. In the state of Tabasco, anarchists called for all forms of student contests to be eliminated and any kind of activity "organized around competition among students with the purpose of emulation" was frowned upon. ${ }^{20}$ For Tabascan Professor José Ochoa, sympathy and cooperation would substitute for competition. ${ }^{21} \mathrm{He}$ maintained that emulation would lead to or degenerate into rivalry and envy, the opposite sentiments to solidarity. ${ }^{22} \mathrm{An}$ aesthetic of freedom that included unbolted 
chairs, open-air classrooms, and the elimination of "rows of rigid tables" would further encourage the "free associations of students and the bonds of solidarity and cooperation that [are to] characterize [this] new order." ${ }^{23}$

de la Luz Mena's 1917 tract entitled De las tablillas de lodo a las ecuaciones de primer grado- "From the Clay Tables to the Equations of First Degree"- promoted an atmosphere of "complete liberty," where students produced their own school projects simply by playing with "clay tables" and then naturally proceeding to the learning of mathematics, without, seemingly, teacher supervision. ${ }^{24}$ Professor Elena Torres, speaking at the First Socialist Congress held in Motul, Yucatán, from March 29 to 31 of 1918, explained the schools' goals in terms of the acquisition of two kinds of knowledge: a "knowledge of immediate application" to be acquired "by sowing fields, in workshops, in the experimentation cabinets of the same school," and a more sophisticated knowledge of "social life" to be acquired in the conduct of life in the school, giving way to practices of liberty." ${ }^{25}$ Scientific principles would be "deduced from ordinary work." ${ }^{26}$ Inquiry, rooted in human experience and free of dogmatism and authority, would usher in a new man free to pursue, innovate, and create: a child-scientist. Anarchist activists defended Deweyan child-centered education during the Pedagogic Congress of 1915 in Merida specifically for that purpose. ${ }^{27}$ de la Luz Mena argued that anarchist schools "must let children live for themselves; the child is a sun around which all factors of education move, he is the center of reference for all organization according to John Dewey."28

The texts, proclamations, and regulations of these anarchist schools suggest that there was in fact a duality to this project. Another dimension of the project consisted in an active project of exclusions necessary to make the democratic order of the school possible. On the one hand, the notion of freedom inscribed in anarchists' writing implied the destruction of the "artificial" barriers of Catholicism, its dogmatic impositions, and its opposition to free inquiry. In this way, the school, structured around the "principles of life," could accommodate itself to a society whose logic became transparent. The school community-its social world of clubs, organizations, newspapers, and activities-would find in the outside world a congenial environment for its own reproduction only when that world was free of any dogma.

On the other hand, racial considerations became paramount in the pluralistic world of the Yucatán province, a social reality very much the opposite of the racially homogeneous classrooms of Europe, where only class differences impinged on revolutionary projects such as Ferrer's. ${ }^{29}$ In Mérida, racialized fractures in social consciousness between school, society, and home prevailed. Thus socialization, as an educational objective, acquired a much broader significance in an urbanized and racially miscegenated society such as Mérida. Most anarchist texts affirmed a civilizational mission for the Natives of Mexico as a supplement to the larger task of creating a democratic community inspired by European and American models. ${ }^{30}$ 
This mission implied an intimate and accurate knowledge of the conditions of students' homes and their parents' social practices. Their culture had to be available for transformation the same way as the natural world. By displacing Native autonomy, society would be consistent with the "principles of life": secular, available to continuous inquiry, and homogeneous. Nothing could have been more important in a nation of innumerable particularities such as Mexico, where many communities co-existed uneasily, and at times violently, with each other.

In spite of these tensions, Dewey's notion of associated living shared an important place in anarchist thought, which aimed to achieve democratic life in a world of limitless possibilities for individuals sharing the same purpose. Anarchists opposed anything that promoted uniformity and conformity in the schools. They eliminated textbooks, examinations, awards and punishments and rejected any form of mediating authority, such as the church and state. They justified antiintellectualism on the grounds that only knowledge that was practical was necessary for democratic life. ${ }^{31}$ Anarchists demonstrated that radical aspects of Dewey's pedagogy could find a congenial atmosphere in Mexico. They helped advance the notion that ideas were the product of man's labor and his engagement with the world, and that democratic life could be conceived as the end point of social revolution. This aspect of education that conceived democracy as its ultimate end constituted the most Deweyan element of anarchist education in Mexico.

\section{The escuelas activas Movement}

While the racionalista project shared the universal aspirations of the world-wide anarchist movement, most other projects of education in Mexico that invoked Dewey reflected a firm commitment to the creation of a Mexican nation. This meant that the purposes of education focused on the creation of a nationalist consciousness that would facilitate a modern and just industrial order deemed possible in Mexico. These two dimensions of modernity-nationalist consciousness and economic development-complemented each other. Nationalist consciousness spoke to the desire to create the underlying unity of purpose that would make possible material progress and would also socialize what Eulalia Guzmán, a principal actor in the movement and writer of La escuela nueva, denominated the "isolated individual, ${ }^{32}$ a common moniker for the subject atomized by a racially (and geographically) diverse society such as Mexico. It would realize the Mexican liberal dream of reconciling order and progress. This aim animated the escuelas activas movement that promoted the principles of progressive activity-based education in Mexico during the early 1920 s.

The escuelas activas movement in Mexico City moved Dewey and American progressive education more to the center of its nationalist vision. Pedagogues, such as Guzmán, imagined Mexico within a comparative framework where the progressive aspects of American society stood as an important model for a future Mexican

\section{E\&C Education and Culture}


society. America consisted in an ordered and progressive social order where the methods and organizational capabilities of Americans explained its amazing progress. ${ }^{33}$ This was the America found in the classroom, but also the America that made these classrooms possible. In that classroom, Mexican teachers found discipline and order without the need of coercion. This was a product, according Guillermo de la Rosa, of America's "admirable political and administrative organization," ${ }^{34}$ which, as Guzmán claimed, reconciled order and progress in a synthesis of "utility and culture." ${ }^{35}$ She expressed admiringly that in the United States "anything that is not of utility outside the school nor possesses an educational value to justify its inclusion in the program ... is thrown out of the primary school in order to substitute for the simple equation and the percentage." ${ }^{36}$ Science had replaced dogma: "Anything that harks back to scholastic discussions .... is thrown out," she exclaimed. ${ }^{37}$ The managerial liberalism teachers praised spoke to the teaching and use of science as form of inquiry and thought, exemplified by the use of the inductive method. ${ }^{38}$ Guzmán and the Mexican teachers read modern forms of discipline encountered in the United States not as the product of its industrial society, but as its cause.

In Guzmán's visit to New York's Angelo Patri Deweyan schools, the Bronx experiment founded by school principal Angelo Patri, Guzmán spoke admiringly of the American classroom as a laboratory for democracy. Patri had used Deweyan education in public schools as an alternative to the enforced Americanization projects favored by other progressives, which he thought were coercive of, if not outright hostile to, the students' heritage and language. ${ }^{39}$ Here Guzmán observed Deweyan schooling practices directly, which she compared to those of Tolstoi in Russia and Tagore in India. ${ }^{40} \mathrm{Her}$ recollections indicate that Patri's schools exemplified for her Dewey's "education for life," devoid of the dogmatic tyranny of book memorization and the political control it implied. She observed admiringly how "[students'] associations, cooperatives, elections, [were] not written on a school notebook, they wanted them living in the schools." ${ }^{\prime 41}$ Patri's schools suggested for her the model for Mexico's "future social order." "Why do they need notebooks, why summaries of civics if they have the living practices of civic life," she exclaimed. "When [I] wished to talk to them [the students] about respecting the right of the other, they were already respecting the labor of others, because they understood the value of such labor and did not desire unto others what they did not desire to be done unto them, ${ }^{\text {"42 }}$ she concluded.

In her book, Guzmán lionized Arturo Oropeza's "Francisco I. Madero" school, financed in part by Mexico's Directorate of the Campaign Against Illiteracy, and founded in 1921 in Mexico City partly as a Deweyan activity-based school, whose purpose consisted in translating this atomized subject into a producer citizen or niño productor (producer-child), fully socialized by the social world of the school. This world consisted of social organizations such as banks, technical councils, irrigation committees, a Cooperative of Consumption, a second Cooperative on 
Production, and a Commission for the Regulation of Prices, which students could manage as fraternal and egalitarian enterprises. ${ }^{43}$ Students also formed a Junta de Trabajo or Labor Board, a Board for the Protection of Children, a Board of Justice, a Board for Material Improvements, and other corporate bodies to prepare them for a life of activism outside the school, ${ }^{44}$ and they engaged with possible solutions to Mexico's national problems, such as poverty, land and labor issues, and created in the school Mexico's "future social order."

Guzmán's ideas reflected the intense desire of Mexican intellectuals, ravaged by war and spiritually burdened by the poverty of Mexico, to imagine a nation where virtues flowed organically from human interaction and not from external authority. She wrote La escuela nueva o de la acción in 1923 as a manifesto for a new movement imagined along Deweyan lines of the cultivation of the self, scientific practice, communal work and cooperation, fraternity and mutual support. Discipline in the classroom, based on "liberty in work and happiness," would displace "awards and punishments." Classrooms were to become "fields of observation and experimentation ... factories and workshops" so as to provide the basis for a new kind of experimental self. ${ }^{46}$ Like many other liberals, she imagined the school's community as "natural," providing the necessary common purpose to permit experimentation and creativity. In her discussion of Oropeza's school, she praised the classrooms' desorden armonioso, a common phrase meaning "harmonious disorder. ${ }^{{ }^{347}}$ Eulalia Guzmán called it a "disorder that follows the varieties of life, within a natural order." ${ }^{38}$ She praised Oropeza's students because they exercised in class their "broad faculties to govern themselves in order to give foundation and see with clarity the problems of life, and not to vegetate in a school within an environment of artificiality, more artificiality, pure artificiality." ${ }^{\prime 49}$ The political order of the school, free from the religious oppression of the mind, could be self-sustaining and thus deemed natural. Oropeza himself related how "cleaning brigades," one of the first spontaneous associations formed by children, cleaned the school and swept the streets of the barrio and the front of each child's home.

Guzmán argued that in Oropeza's school there was no planning at all as students set the pace of learning. As in other similar experiments, textbooks, blackboards, maps, considered "material created for the exploitation of the child rather than his benefit," were eliminated. Oropeza claimed to have eliminated schedules, timetables, and any kind of pre-conceived planning to allow children to dictate the pace of learning through their own work. Arturo called agricultural tools, a replacement for books and chalk, something "natural." ${ }^{50}$ Guzmán relates how Oropeza’s students' learned about their nation from their experience in school:

at first ... because the extension of land [in the school] was large and because relatively few students wished to work the land (a few students wondered why they had to work in school since they had always been convinced that in school one does not work but merely reads) ... [the agrarian problem] 
did not arise in their minds ... [According to Oropeza] "as soon as they saw the pecuniary results and the satisfaction they felt in being producers, the demand for land grew and all ask their teachers for their share of it ... we saw with pleasure ... how this problem was easily resolved by the children themselves ... since they came up first with the idea that any share of the land had to be possessed equally by all and that for this sharing to be ordered they must appoint a commission of their peers. Thus children practiced elections, understood the value of the individual in the collectivity, and, felt the weight of the national problem of socializing land." ${ }^{1}$

One may doubt that students spontaneously created all these organizations in the school, let alone had time even to read a book, but the idea that students' personal and national interest possessed a natural correlation constituted the key point in this narrative.

She continued:

when we intended to issue regulations for the children, they had already done so by themselves; when we intended to demand punctuality, the child cared more about being punctual than ourselves ... when we intended to talk to them about equity in the distribution of lands and profits, it was realized that they never desire for any one child to gain more than the other, or more land than the other, because they always saw that as an injustice; when we intended to teach them about virtue, they themselves praised the working child and chose their leaders by their virtues and not by their defects .... [A]s can be seen ... the problem of discipline resolves itself automatically as a result of a life of work, of liberty, which the children are living." ${ }^{52}$

\section{Teachers' Debates and the Journal "Educación"}

The more nationalist the educational project, the likelier the United States (and Dewey) became the focus of discussion. ${ }^{53}$ In congresses, conventions, and public meetings with leaders of the Secretariat of Public Education (SEP), radical teachers defended Deweyan pedagogy when it demarcated the domain of teaching as separate from that of the state and prioritized democratic and egalitarian social relations as the ultimate end point of modernity. Many teachers supported American child-centered education because it affirmed the inviolable bond between student and teacher. The Second Commission of the Second National Teachers Congress, held in Mexico City on December of 1920, declared itself in favor of Dewey's escuela activa as a way to individualize instruction, declaring that: "[if] all children were to be absolutely equal, if one child were to be identical to the other ... then the school would fulfill its noble goals by instructing teachers with old ideas . . [yet] texts show us that there is no such psychology of the child, but the psychology of this one child, and that one child ..." ${ }^{54}$ The Congress expressed its approval of 
the new pedagogy, declaring that its "basic principle is to be liberty, both for the pupils as for the teachers, without any other sanction than the sentiment of one's responsibility." ${ }^{35}$

Although opposed by teachers who argued that Dewey's escuela activa would promote chaos by fostering the radical individuality of each person and by claiming that no authority could evaluate the relationship between student and teacher, sentiment in favor of activity-based education grew. ${ }^{56}$ In the First Mexican Congress on the Child held in Mexico City in 1921, Lisandro Calderón, condemned any education whose "principal objective," he argued, "was mastering certain symbols as the only access to culture." ${ }^{57}$. Teachers who followed Deweyan progressive education in the Congress argued that education could not be secured simply by teaching culture through the European classics, as the newly appointed Secretary of Public Education, José Vasconcelos, claimed, but instead by democratizing social relations among students. ${ }^{58}$ Calderón defended American education as a place where "these transformations [had] been implemented rapidly": the American child," he argued, "has in the school a true place for work and education." 59 Thus the United States stood firmly, now more than ever, at the center of teachers' debates on Dewey.

Still, these sentiments in favor of an education free from state constraints conflicted with the desire to unify the nation, a response to the weakness of Mexico, devastated by civil war and American imperial incursions, which intensified the need to unify a politically and racially fragmented nation in order to defend the state. Lisandro Calderón defended the use of Deweyan education in the schools precisely because it favored "a society ... [that] maintains itself together because it labors in a common direction, possesses a common spirit and has, as a reference

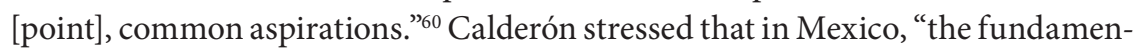
tal reason why the school today cannot organize itself as natural and unify society is precisely because it lacks this element of a common and productive activity. In the field of play and in sports we don't see a spontaneous and unavoidable social organization... [today's] schools are lacking in the motivation and cement of social organization." ${ }^{1}$ "If," continued Calderón,

"our natural resources remained unexploited or if only foreigners were to take advantage of them, I would understand this as the result of our deficient theoretical education. But if we get children used to action, their mental state will change; it will take off in new directions and will generate acts in a more positive sense. And the Motherland, who expects so much from her good sons and the course of progress, will finally be able to count on an army of workers well armed for the struggle ... this does not mean that scientific speculation will be seen with indifference... what is wished is to orient education towards action ... ${ }^{\prime 62}$

The preoccupation with national unity moved fears of racial degeneration or, as Calderón put it, the "racial apathy" of the Mexicans, ${ }^{63}$ to center stage, creating a 
"national character" resting on the belief that racial miscegenation had produced the Mexican's apathetic and atomized individual, an idea that reflected a growing consensus that race and modernity intersected only in that historical space where racial homogeneity prevailed. Calderón's intervention bears reproducing in full given the salience of race, now firmly at the center of national discussions on education among teachers favoring Dewey. Calderón stated that,

our national character is generally apathetic and not too much inclined towards action. We must recognize this ... the majority of the Mexican people proceeds from the mixing of two races: the Spanish and the Indigenous. The first one was proud, heroic, and a dreamer; the other one was resigned and sad, without aspirations and at times estranged from the social conditions of the nation, in spite of the fact that in the past it demonstrated its potent energy. From this mixture comes the Mexican people who are dreamers, who are heroic but also sad and resigned ..."64

Progress and melancholia did not mix.

Calderón's arguments demonstrate that the appropriation of American education, and specially Dewey, was intended to save the Mexican nation, not to Americanize Mexico. If it is true, as Calderón affirmed, that the Mexican school was to be transformed "just like School 45 of Indianapolis where children build a doll's house first by drawing a plan, gathering material, building up, decorating and endowing the new house with its park and cultivated land," ${ }^{65}$ it was equally true that the school needed to be purely Mexican. Yet, at the same time, the concern with common purpose, and the need to build an industrial and powerful nation strong enough to withstand the erosion of sovereignty brought about by American penetration of markets and politics, meant that the comparative disadvantage between the United States and Mexico stood as the implicit point of reference for the importation of foreign ideas such as Dewey's. ${ }^{66}$

Calderón's intervention also demonstrates how, along with the issue of national unity, another powerful idea took hold of the imagination of these teachers: that Mexicans needed to reach a new "mental state" that could move the nation in "new directions" and generate modernity from within the nation. This moved the debate away from discussions of structural issues, such as land redistribution. Polemical texts by José Antonio Rodó, Edmond Desmolins, Victor Arreguine, and Gustav Le Bon had begun circulating in Mexico since the turn-of-the-century, providing a public forum for the proliferation of discourses of racial decline and the ascendancy of the "Anglo-Saxon" race in world history, profoundly influencing the teachers of Educación. ${ }^{67}$ "If one wishes to summarize in one word the fundamental psychological differences that separate Latin learning from Anglo-Saxon learning, Gustav Le Bon states the first one rests only on the study of books, while the second one exclusively on experience," argued Deweyan supporters Lima and Rentería. ${ }^{68}$ The solution was to educate a new practical man of modernity oriented towards vida or life. 
The primacy of John Dewey in the teacher's movement, tied so much to these discourses, was cemented by the publication of Educación, a journal of politics and pedagogy published in Mexico in the years of 1921 and 1922 and sponsored by the Columbia University. John Dewey was listed as a member of its editorial board, along with other faculty at Teachers' College, such as William H. Kilpatrick. In its pages, the rhetoric of education coalesced around the principio de la acción, a set of techniques and proposals that unified all kinds of projects to formulate modern Deweyan classroom practices around the concept of activity or acción. The journal's leading ideas became the foundation for the Bases para la organización de la escuela primaria conforme al principio de la acción (Bases for the Organization of Primary Schools according to the Principle of Action), the law which inscribed Deweyan ideas in Mexican education and which was published in the journal. The Bases supported the adoption of Kilpatrick's project method as a way to create the much-desired "harmonious disorder." It also promoted centros de acción to produce unity in the classroom when one single task stood at the center of group activity. ${ }^{69}$

Thus the significance of Educación resided mostly with a slight but significant shift, when discussing on Deweyan education (and American modernity in general), towards the creation of a new subject of modernity and away from the previous emphasis on social justice and democracy. This meant undertaking a search for ways of thinking that promoted creative growth in the individual. Mexican teachers, such as Manuel Barranco, Lucio Tapia, Marcelino M. Lima, Marcelino Rentería, and Moisés Sáenz, perhaps the most important advocates of Deweyan schooling in Educación, seemed overwhelmed (like most Mexican intellectuals) by Mexico's disempowerment vis-à-vis the United States, in particular, and between Latin American and English-speaking nations, in general. A model for a new Mexican subject, declared Barranco, was "the inventor, the discoverer, the wise." ${ }^{70}$ Lucio Tapia declared that México needed to transform its men into pragmatic individuals who could produce not ideas, but things. Marcelino M. Lima and Marcelino Rentería called this new man the "Struggler-for-lifer" (in English)." This "struggler-for-lifer" was entrepreneurial, akin to the American businessman, a Mexican version of the self-made man. For them, Deweyan education promised the transformation of the Mexican self from a Latin "hombre teórico" or theoretical man to a practical and entrepreneurial men edified by labor."72 "God Himself assists the Saxon, while we ourselves kill each other over dogma ...,"73 declared José Vasconcelos. The Bases went on to declare that the new education would provide "the foundation for scientific investigation ... to awaken the child to action ... to favor the instinct of the child." ${ }^{\prime 4}$

The Mexican Native stood in opposition to the entrepreneurial man. Deemed an "obstacle to progress," national unity needed the transformation of the Native into a "factor of production." "What solution is there for this national problem," wrote Tapia in Educación, "if the Indian cannot advance and we cannot back 
down?"75 For Tapia, the teacher to the Indians would be a "new Messiah ... bringing the Gospel of civilization." ${ }^{\text {76 }}$ For teachers such as José Bonilla, the Indian's life had to be absolutely modified and transformed, his family life severed from village loyalties, and his physical being separated from the home. Bonilla even proposed his own version of the school as "a community in miniature," 77 imagining the school as providing an artificial environment that could favor the transformation of the Indian." ${ }^{78}$ The authors in Educación all agreed that modernity necessitated the complete transformation of the Indian, a project not subject, of course, to democratic deliberation, but instead to state imposition.

The pedagogues of Educación assumed that racial homogeneity constituted the most important reason for American success and even opponents of the Deweyans agreed. Antonio Caso argued that, "the collective soul of the Mexican has not coalesced yet in definite and characteristic form; and it is very difficult that there exists a proper and adequate scientific study of anything if the object itself of research has not yet realized itself in its integrity and plenitude." ${ }^{.79}$ According to José Vasconcelos, then the head of education in Mexico, "they [the North Americans] do not bear in their blood the contradictory instincts of the mixture of dissimilar

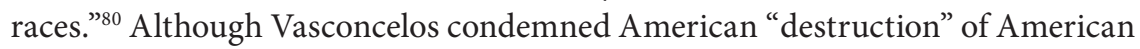
Indians, he conceived modern education in Mexico as encompassing Native life in its totality: "the flowering of the native within the domain of the universal." ${ }^{11}$ Jurist Emilio Rabasa put it more succinctly: "the Anglo-Saxon communities, were founded in the New World not by conquest but by the occupation of land, and, instead of forming unions with the Natives, they denied them all contact with their race ... increasing their hereditary tendencies of individualism, autonomy, and thus able to experiment without interruption in the practices of ordered government for their mutual benefit." ${ }^{22}$

These discourses on race tempered the optimism prevalent in the previous projects that invoked Dewey, casting a melancholic shadow over the very meaning of progress. Lucio Tapia imagined progress now "not [as] an 'angel,' but as a 'satanic exterminator of the Apocalypse."'83 In the name of progress, he said, Indians, "the ancient and great people who owned this land that we have violently taken away from them ... the authors of the civilization we have destroyed ... the masters of yesterday," have been enchained and conquered." ${ }^{84}$ Yet, progress being inevitable, the new educational mission for Mexico could be imagined as a tragic yet necessary continuation of the centuries-old European project of conquest, another conquista. The Bases" dictum that "the school must reproduce the environment of the home" ${ }^{15}$ was prefigured in the state's mission to know the intimate life of its citizens and transform it for nation building purposes. The Bases committed the schools to "penetrate the current of material and spiritual progress of the society wherein [the child] will live and struggle," faithful to Dewey's desire to create a continuum between school and society, ${ }^{86}$ but also setting the basis for state intervention. Schools 
were to be given the task of transforming the intimate lives of Indians to make way for civilization. The civilizational mission thus became an essential component of state projects based on Deweyan education, a mission justified as necessary to create a nation with a common set of values and where racial difference would not stand as an obstacle to the efficiency of the entrepreneurial body.

\section{End of the Military Phase of the Mexican Revolution}

Pedagogical discourses invoking Dewey could have multiplied and transformed themselves in multiple ways, as they had been doing since the earlier anarchist projects. Yet, historical contingencies led to Dewey becoming the patron saint of Mexican revolutionary education in 1923. The military occupation of the state of Yucatán in 1915 by General Salvador Alvarado, which precipitated the demise of the anarchist and socialist experiments in education that had been established there, paved the way for the appropriation of Deweyan education by the nation state. The Deweyan features of anarchists' schools appealed to Alvarado, who had familiarized himself with American pedagogy, especially new ideas emanating from the University of Chicago. Alvarado expressed an appreciation for the qualities of American pragmatism and Anglo-Saxon Victorian virtues in general. He became an avid reader of the literature of personal uplift, where Anglo-Saxon cultural traits offered clues to Anglo-Saxon success and character. He read Samuel Smiles, the Victorian writer and novelist, and the literature of uplift and self-esteem produced in the United States. ${ }^{87}$

For a man who believed that Catholic education had created an artificial world embodied by the oppressive figure of the authoritarian teacher who interpreted life for the child "by the dogmatic imposition" of his beliefs and "the fateful principle of magister dixit," 88 the practicality of the American character reigned triumphant because it expressed the ability of the student to orient himself to experience. Dewey's notion of the "school as miniature community" compelled Alvarado to suggest ways schools could create a national consciousness by providing a vision of the nation as a real entity through experiential learning. Schooling could create within the space of the school a vision of society "as it really was." He invoked Dewey in this respect when he said, "Education must be a social process; a process whereby the individual participates in the social consciousness of the people or the race he belongs to. The school is a social institution and for its proper functioning, for it to socialize the child, it must present the form of a small community wherein social life is represented in miniature as it really is, as it is seen in the home, in the neighborhood and in the field of play." ${ }^{89}$ In Alvarado's mind, that "real life" was the nation. The Deweyan principle of the "school as a miniature community" and the "assimilation of school to society" formed the foundation for Alvarado's project to acculturate Mexican natives to civilization and create selfconsciousness through work-based education. Socialization would teach them 
"how to read, write, or count ... it means work ... intelligent work . . . to work in a conscious mode." ${ }^{90}$ In 1918, Alvarado passed a law for primary schools calling for fields, orchards, and workshops designed to derive learning from activities. ${ }^{91}$ Boy Scout groups were imported from the United States to promote solidarity and the practical principles of everyday life. ${ }^{92}$

Along with the appropriation of progressive education techniques came the absorption of these same intellectuals into the revolutionary process, leading to the appointment of Moisés Sáenz, a self-professed disciple of Dewey and former student at Teachers' College, as the sub-secretary of Education in 1923. These pedagogues, many of them Protestants, had placed an enormous emphasis on the American entrepreneur as their model for the common man: an everyday man with extraordinary abilities and a practical orientación para la vida or "orientation to life." As Jean-Pierre Bastian has noted, Sáenz "took from Anglo-Saxon liberal Protestantism this concept of the individual engaged in an effort for the common good ... [where] ... private and public interest must coincide in the defense of a nationalism open to foreign pedagogical models and to the economic model from North America." ${ }^{93}$ Most, like Sáenz, had been educated according to the principles of progressive education in mission schools and became useful for a state desirous of displacing the power of Catholicism in the Mexican government. These intellectuals led a new phase in the dissemination of Dewey's ideas in Mexico.

\section{CONCLUSION}

It is difficult to evaluate the fidelity of these projects to Dewey's own thought, since the Mexican actors for the most part invoked Dewey as a prophet of national salvation rather than seeking to engage the philosopher's works in depth. Positing the existence of a "true" Dewey may also constitute a problem when it veers into dogma. Mexico's early uses of Dewey occurred in a quasi-mystical engagement with American modernity and with the messianic possibilities of Dewey's education, in particular, and American progressive education, in general. The nature of the dissemination of his ideas occurred mostly in relation to "maxims," such as the "school as a miniature society" or the idea that "the schools must reflect the principles of life." These powerful ideas structured an important phase in Mexico's educational history and constituted a powerful conceptual tool to conceive the future nation with the same messianic zeal that characterized the spirits of American educators in the early $20^{\text {th }}$ century. As Richard Hofstadter reminded us, progressive education "was presented to the world not simply as an instrumentality but as a creed, which went beyond the hope of this or that strictly educational result to promise some kind of ultimate salvation for individuals or for the race." ${ }^{94}$ It would usher in, as Dewey himself proclaimed, "the true kingdom of God."95

It is clear that from the beginning that creating an underlying unity for the nation-assumed by most Mexicans to exist already in the Anglo-Saxon racial 
fabric of the United States-constituted the main problematic in the appropriation of Dewey's thought in Mexico. Mexican teachers believed that creating a shared set of values would not occur in conditions similar to those of the United States, which had indeed been violent. "We cannot annihilate [the Indian] as the English colonials did with the Redskins or the buffalo and then gather them pitifully," exclaimed Salvador Alvarado, only to "populate reservations and parks with them." Mexico, facing a majoritarian native and mixed raced population, had to pursue other means to convert the Native. Acts of exclusion did not seem incongruous with the American progressive spirit. Social efficiency would have seemed a product of selection (and thus exclusion). Mexican intellectuals had visited various experimental schools in the United States, including Dewey's laboratory school, which for the most part functioned by selecting both teachers and students in order to provide that common fabric without which the experimental school would not achieve its effectiveness. In other words, unity of purpose could be conceived as an external imposition: as in the laboratory's conditions of possibility.

Thus when pragmatism met revolution, to paraphrase Engerman, it gave way to force as the means to attain peaceful ends. Dewey had argued that when "certain ends are desirable," it did not mean that, "those ends and nothing else will result from the use of force to attain them." ${ }^{97}$ Yet it was not clear whether he intended to apply this idea to all societies. Oftentimes he referred to the United States as a nation possessing an exceptional foundation for democratic life; under other conditions, force could be employed to "permit the method of intelligent action." In fact, Dewey claimed that,

to profess democracy as an ultimate ideal and the suppression of democracy as a means to the ideal may be possible in a country that has never known even rudimentary democracy, but when professed in a country that has anything of a genuine democratic spirit in its traditions, it signifies desire for possession and retention of power by a class, whether that class be called Fascist or Proletarian ... the one exception-and that apparent rather than real-to dependence upon organized intelligence as the method for directing social change is found when society through an authorized majority has entered upon the path of social experimentation leading to great social change, and a minority refuses by force to permit the method of intelligent action to go into effect. Then force may be intelligently employed to subdue and disarm the recalcitrant minority.98

The issue of unity in Mexico was an ambivalent one. Imagined at times as absent, at other times it was something actually real but impossible in practice due to the artificial order imposed by the Church, which nurtured divisions within the national body. The discourse on the "principles of life" and the accommodation of the school to those principles veered between the descriptive and the prescriptive. At times it referred to an already underlying unity, which the school would 
redeem for the nation, at other times to a future "social order," which the school would cultivate. The discourse on the "principles of life," relying on an opposition between "real life" and an "artificial order," also replicated the logic of American progressive education. "The notion of education advanced at the turn of the century," writes Hofstadter, "was romantic in the sense that [progressives] set up an antithesis between the development of the individual-his sensibility, the scope of his fancy, the urgency of his personal growth-and the imperatives of the social order, with its demand for specified bodies of knowledge, prescribed manners and morals, and a personal equipment suited to traditions and institutions. Theirs was a commitment to the natural child against artificial society." ${ }^{\text {99 }}$ In Mexico, the ambivalence between the artificial and the real complicated the reception of Dewey.

Finally, the shift towards ways of thinking exemplified by Educación led to the prioritizing of individual growth over concerns with democracy and justice. Democratic ends, of course, were not forgotten, but the uses of Deweyan education turned towards the teaching of productive ways of thinking, in other words, to ushering some kind of cognitive revolution in the Mexican self. This corresponded with Deweyan thought. Dewey did not reduce human activity to just growth and productivity, but his philosophy of education did emphasize productive forms of inquiry. According to Larry Hickman, Dewey's notion of inquiry, as the defining feature of his philosophy and the foundation for social scientific thinking in general, did just that. ${ }^{100}$ Hickman argues that, "progress in the sciences, as well as in common sense inquiries, requires that the results of prior inquiries be treated as raw materials for further inquiries, and not as determinate results, established one and for all." ${ }^{\prime 101}$ Nothing could have been more attractive for Mexican pedagogues of the time, concerned especially with how the Catholic Church fostered exactly the opposite vision in Mexico, militating against free inquiry and promoting a purely "consummatory" orientation to life.

In many ways, the Catholic order in Mexico thrived on what Dewey called in Experience and Nature "magical exercise and superstitious legend." He explained there that in a political order infused with magic, the "primary interest lies in staging the show and enjoying the spectacle, in giving play to the ineradicable interest in stories which illustrate the contingencies of existence combined with happier endings for emergencies than surrounding conditions often permit. It was not conscience that kept men loyal to cults and rites, and faithful to tribal myths. So far as it was not routine, it was enjoyment of the drama of life without the latter's liabilities that kept piety from decay." ${ }^{102}$ This "phase of experience," he continued, "manifests objects, which are final. The attitude involved in their appreciation is esthetic." 103 Hickman explains that, for Dewey, "primitive magic and religious practices fail[ed] to become inquiry precisely when and because their interest [were] focused on intrinsic meanings as final and not as productive of further significance: extrinsic meanings or instrumentalities are merely incidental to such 
practices. These societies therefore reverse[d] the pattern of effective technological inquiry." 104 "As direct appreciative enjoyment exhibits things in their consummatory phase," wrote Dewey, "labor manifests things in their connections of things with one another, in efficiency, productivity, furthering, hindering, generating, destroying." Most teachers in Mexico invoking Dewey in fact searched for ways of thinking where, as Hickman argues, "production [would take] precedence over and [become] a guide to practicality." 105 Dewey's ideas on this matter came to possess great import for Mexican pedagogues because they identified the possibilities for progress within specific modes of thought or ways of thinking that were productive rather than purely consummatory. Magic led to the reproduction of familiar worlds, and not to the creation of new ones.

Mexicans desired progress. By 1923, this vision of Dewey came to define the state project that followed in its Deweyan form: creating the practical man of modernity.

\section{ACKNOWLEDGMENTS}

I would like to express my gratitude to Jessica Wang and Valerie Matsumoto for their support and advice throughout my research on Dewey. I also would like to thank Robin Derby for her valuable ideas on Latin American and Mexican history.

\section{BIBLIOGRAPHY}

Aguirre Beltrán, Mario. Revista El Maestro, 1921-1923: raíces y vuelos de la propuesta vasconcelista. México: Universidad Pedagógica Nacional, 2002.

Arreguine, Víctor. En que consiste la superioridad de los latinos sobre los anglosajones. Buenos Aires, 1900.

Avrich, Paul. The Modern School Movement: Anarchism and Education in the United States. Princeton: Princeton University Press, 1980.

Bar-Lewaw, Itzhak M. La Revista “Timón” y José Vasconcelos. México: Casa Edimex, 1971. Bastian, Jean-Pierre. Protestantismo y sociedad en México. México: Casa Unidad de Publicaciones, 1983.

Bookchin, Murray. The Spanish Anarchists: The Heroic Years, 1868-1936. Oakland: AK Press, 1997.

Basave Benítez, Agustín. México mestizo: Análisis del nacionalismo mexicano en torno a la mestizofilia de Andrés Molina Enríquez. México, Fondo de Cultura Económica, 1992.

Boyd, Carolyn P. “The Anarchists and Education in Spain, 1868-1909," The Journal of Modern History 48, no. 4, December 1976, 125-170.

Cárdenas, Joaquín. José Vasconcelos: Caudillo cultural. Oaxaca: Universidad José Vasconcelos de Oaxaca, 2002.

Caso, Antonio. "Problemas Nacionales," Antología filosófica. México, Ediciones de la Universidad Autónoma, México, 1957. 
Chakrabarti, Dipesh. Provincializing Europe: Postcolonial Thought and Historical Difference. Princeton: Princeton University Press, 2000.

Chatterjee, Partha. Nationalist Thought and the Colonial World. Minneapolis, University of Minnesota Press, 1986.

Crespo, Regina Aída. Itinerarios Intelectuales: Vasconcelos, Lobata y sus proyectos para la nación. México: Universidad Autónoma de México, 2005.

Dawson, Alexander S. Indian and Nation in Revolutionary Mexico. Tucson: University of Arizona Press, 2004.

de la Luz Mena, José. La escuela socialista, su desorientación y fracaso. El verdadero derrotero. México, 1941.

Demolins, Edmond. A quoi tient la superiorité des anglo-saxons. Paris: FirminDidot et cie, 1898.

Desmolins, Edmond. A science sociale depuis F. Le Play, 1882-1905. Classification sociale resultant des observations faites d’après la methode de la science sociale par Edmond Desmolines. Paris, 1905.

Derrida, Jacques. Of Grammatology, trans. Gayatri Chakravorti Spivak. Baltimore: The John Hopkins University Press, 1998.

Dewey, John. Collected Works. Edited by Jo Ann Boydston. (Carbondale: Southern Illinois University Press, 1972-1985).

Educación, Revista Mensual. Vol. 1-3, México, 1922-1924.

El Primer Congreso Feminista de Yucatán, convocado por el C. gobernador y comandante militar del estado, Gral. Don Salvador Alvarado. Mérida: Talleres Tipográficos del “Ateneo Peninsular," 1916.

Engerman, David C. "John Dewey and the Soviet Union: Pragmatism meets Revolution," Modern Intellectual History, 3, no. 1, 2006, 33-63.

Fell, Claude. José Vasconcelos. Los años del águila. México: Universidad Nacional Autónoma de México, 1989.

Ferrer, Francisco. The Origins and Ideals of the Modern School, trans. by Joseph McCabe. New York: G. P. Putnam's Sons, 1913.

González Navarro, Moisés. Raya y tierra: la Guerra de castas y el henequén México: Colegio de México, 1970.

Guzmán, Eulalia. La escuela nueva o de la acción. México, 1923.

Hale, Charles A. "The Civil Law Tradition and Constitutionalism in TwentiethCentury Mexico: The Legacy of Emilio Rabasa," Law and History Review, vol. 18, no. 2, Summer 2000. http://www.historycooperative.org/journals/lhr/18.2/ hale.html

Hickman, Larry. “Dewey's Theory of Inquiry," Reading Dewey: Interpretations for a Postmodern Generation. Bloomington: Indiana University Press, 1998.

Hickman, Larry. John Dewey's Pragmatic Technology. Bloomington: Indiana University Press, 1990.

Hofstadter, Richard. Anti-Intellectualism in American Life. New York: Vintage Books, 1962, 1963. 
Knight, Alan. The Mexican Revolution, vol.2: Counter-revolution and Reconstruction Lincoln: University of Nebraska Press, 1990.

Lewis, Stephen E. The Ambivalent Revolution: Forging State and Nation in Chiapas, 1910-1945 Albuquerque: University of New Mexico Press, 2005.

Ley de educación primaria. Mérida: Departamento de Educación Pública de Yucatán, 1918. Lima, Salvador M., and Rentería. "La escuela nueva de la acción: los errores de la vieja escuela," Educación, vol. 2, no. 4, August 1923.

Lomnitz-Adler, Claudio. Exits from the Labyrinth: Culture and Ideology in the Mexican National Space. Berkeley: University of California Press, 1992.

Marentes, Luis A. José Vasconcelos and the Writing of the Mexican Revolution. New York: Twayne Publishers, 2000.

Martin, Jay. The Education of John Dewey: A Biography. New York: Columbia University Press, 2003.

Martínez Assad, Carlos, ed. Los Lunes Rojos: la educación racionalista en México, 1st. ed. México: Secretaría de Educación Pública. Ediciones El Caballito, 1986. Memoria del primer congreso mexicano del niño patrocinado por "El Universal". México, 1921.

Molina Enríquez, Andrés. Los grandes problemas nacionales México: Impresora de A. Carranza e Hijos, 1909.

Müller, Detlef, Ringer, and Simon, ed. The Rise of the Modern Educational System: Structural Change and Social Reproduction 1870-1920 Cambridge: Cambridge University Press, 1990.

Paoli, Francisco, and Montalvo. El socialismo olvidado de Yucatán México: Siglo Veintiuno, 1974.

Pompa y Pompa, Antonio, ed. Antología Ideológica México: Secretaría de Educación Pública. Primera edición, 1976.

Popkewitz, Thomas, ed., Inventing the Modern Self and John Dewey: Modernities and the Traveling of Pragmatism in Education New York: Palgrave MacMillan, 2005.

Rabasa, Emilio. El juicio constitucional: orígenes, teoría y extensión Paris: Ch. Bouret, 1919.

Rockefeller, Steven. John Dewey: Religious Faith and Democratic Humanism New York: Columbia University Press, 1994.

Rodó, José Enrique. Ariel. 2nd. Ed. Madrid: Cátedra, Letras Hispánicas, 2003.

Ryan, Alan. John Dewey and the High Tide of American Liberalism New York: W. W. Norton and Company, Inc., 1997.

Scott, James C. Seeing Like a State: How Certain Schemes to Improve the Human Condition Have Failed New Haven: Yale University Press, 1999.

Segundo congreso nacional de maestros. Reunido en la capital de la República en los días del 15 al 28 del mes de diciembre de 1920. Obra escrita por el Profesor Higinio Vásquez Santa Ana, Srio. del referido Congreso y delegado de los estados de Jalisco, Michoacán y Chiapas Querétaro, Oficina Tipográfica del gobierno, 1923. 
Silva Herzog, Jesús, ed. La cuestión de la tierra, 1915-1917. Colección de folletos para la historia de la Revolución Mexicana México: Instituto Mexicana de Investigaciones Económicas, 1962.

Vasconcelos, José. La Raza Cósmica, translated and annotated by Dider T. Jaén Baltimore: The John Hopkins University Press, 1979.

Vasconcelos, José. Obras Completas, $1^{\text {a }}$. ed., vol. I-IV México: Libreros Mexicanos Unidos, 1957-1961.

Vaughan, Mary Kay. Cultural Politics in Revolution: Teachers, Peasants, and Schools in Mexico, 1930-1940 Tucson: University of Arizona Press, 1997.

Vaughan, Mary Kay. The Eagle and the Virgin: Nation and Cultural Revolution in Mexico, 1920-1940 Durham: Duke University Press, 2006.

Vaughan, Mary Kay. The State, Education, and Social Class in Mexico, 1880-1928 DeKalb: Northern Illinois Press, 1982.

Wallace, James M. The Promise of Progressivism: Angelo Patri and Urban Education New York: Peter Lang Publishing, 2006.

Wang, Jessica Ching-Sze. John Dewey in China: To Teach and To Learn Albany: State University of New York Press, 2007.

West, Cornell. The American Evasion of Philosophy: A Genealogy of Pragmatism Madison: The University of Wisconsin Press, 1989.

Westbrook, Robert. John Dewey and American Democracy Ithaca: Cornell University Press, 1993.

\section{Notes}

1. The scholarship on the Mexican revolution in the 1920s is very extensive. Among works on Mexico that relate to aspects of Deweyan education during that time see, Alexander S. Dawson, Indian and Nation in Revolutionary Mexico (Tucson: University of Arizona Press, 2004); Alan Knight, The Mexican Revolution, vol.2: Counter-revolution and Reconstruction (Lincoln: University of Nebraska Press, 1990); Stephen E. Lewis, The Ambivalent Revolution: Forging State and Nation in Chiapas, 1910-1945 (Albuquerque: University of New Mexico Press, 2005); Mary Kay Vaughan, Cultural Politics in Revolution: Teachers, Peasants, and Schools in Mexico, 1930-1940 (Tucson: University of Arizona Press, 1997); Mary Kay Vaughan, The Eagle and the Virgin: Nation and Cultural Revolution in Mexico, 1920-1940 (Durham: Duke University Press, 2006); and Mary Kay Vaughan, The State, Education, and Social Class in Mexico, 1880-1928 (DeKalb: Northern Illinois Press, 1982). Some Americanists have referred to this period in the dissemination of Dewey's ideas in Mexico, albeit briefly. Among them see, Jay Martin, The Education of John Dewey: A Biography (New York: Columbia University Press, 2003); Steven Rockefeller, John Dewey: Religious Faith and Democratic Humanism (New York: Columbia University Press, 1994); Alan Ryan, John Dewey and the High Tide of American Liberalism (New York: W. W. Norton and Company, Inc., 1997); and Robert Westbrook, John Dewey and American Democracy (Ithaca: Cornell University Press, 1993). On Yucatán during this era see, González Navarro, Moisés, Raya y tierra: la Guerra de castas y el henequén (México: Colegio de México, 1970); Francisco Paoli and Enrique Montalvo, El socialismo olvidado de Yucatán (México: Siglo Veintiuno, 1974); Vaughn, The State, Education, and Social Class in Mexico, opus cit. 
2. For Mary Kay Vaughan, for example, Deweyan education in Mexico focused on bourgeois concerns with individual character as the basis for modernizing the nation, rather than with revolutionary structural transformations. See Mary Kay Vaughn, The State, Education, and Social Class in Mexico, 1880-1928, opus cit.

3. All interpretations of Dewey in Mexico take for granted the nature of the nationalist discourses that appropriated Dewey in Mexico. If nationalism enters the discussion, it remains tied to a methodology that addresses it purely as sociological phenomena, rather than as a discursive one. On the importance of understanding nationalism as a discursive phenomenon, see Partha Chatterjee, Nationalist Thought and the Colonial World (Minneapolis, University of Minnesota Press, 1986). According to Chatterjee, "the sociological understanding of the phenomenon of nationalism" would lead "inevitably towards a teleology, i.e., a theory of political development." In our case, for example, Vaughan conceives Dewey's pedagogy as serving a particular purpose within the narrative of capitalist development, which is to impose discipline and homogeneity on the work force. Of course, Chatterjee would find this kind of analysis of nationalism limiting, especially because it trivializes the place of nationalism in the history of ideas. I argue that the dissemination of Dewey's ideas in the world is indeed a problem of intellectual history.

4. It is the nature of modern states to set limits to the diversity of life-worlds in order to pursue a developmentalist agenda. See for example, James C. Scott, Seeing Like a State: How Certain Schemes to Improve the Human Condition Have Failed (New Haven: Yale University Press, 1999).

5. Resolving the "national problems," a phrase which refers to Mexico's historical failure to become modern, would lead to the incorporation of Mexico into the universal domain of modernity and thus to full development, both economically and in terms of social consciousness. Andrés Molina Enríquez, a Mexican social scientist, coined the phrase to identify issues of poverty, land redistribution, and race, which he argued had prevented Mexico from reaching the modern. Thus Mexican social science (and the nationalist discourses that would define the appropriation of Dewey in the 1920s) set limits on the nationalist imagination that previous radicals had not. See, Andrés Molina Enríquez, Los grandes problemas nacionales (México: Impresora de A. Carranza e Hijos, 1909). For a discussion of Molina Enríquez's legacy see Agustín Basave Benítez, México mestizo: Análisis del nacionalismo mexicano en torno a la mestizofilia de Andrés Molina Enríquez (México, Fondo de Cultura Económica, 1992) and; Claudio Lomnitz-Adler, Exits from the Labyrinth: Culture and Ideology in the Mexican National Space (Berkeley: University of California Press, 1992). According Claudio Lomnitz, for Mexican social scientists the "definition of the Great National Problems and of their resolution... involve[d] incorporation [of Mexico] to a 'civilization horizon' that transcend[ed] Mexico's borders." The universal character of the modern constituted that "civilizational horizon" for Mexican intellectuals. See Claudio Lomnitz, Exits from the Labyrinth, opus cit.

6. See Engerman, David C., "John Dewey and the Soviet Union: Pragmatism meets Revolution," Modern Intellectual History, 3, 1, (2006).

7. See Jessica Ching-Sze Wang, John Dewey in China: To Teach and To Learn (Albany: State University of New York Press), 2007.

8. See the essays contained in Thomas Popkewitz, ed., Inventing the Modern Self and John Dewey: Modernities and the Traveling of Pragmatism in Education (New York: Palgrave MacMillan), 2005.

9. See Cornell West, The American Evasion of Philosophy: A Genealogy of Pragmatism (Madison: The University of Wisconsin Press, 1989), 5. 
10. The state of Yucatán was situated in an advantageous geo-political location at the intersection of a vast flow of ideas and cultural forms emanating from Europe and the United States, ranging from European anarchism to Deweyan pedagogy, and including American baseball, which had been imported from the United States by Cuban immigrants to Yucatán. The escuelas racionalistas or rationalist schools constituted the most radical of these pedagogical experiments, and they became a model for other socialist schooling projects in México. See Vaughn, The State, Education, and Social Class in Mexico, opus cit.

11. Ferrer's universalism began with his proposition that "truth was universal." See Francisco Ferrer, The Origins and Ideals of the Modern School, trans. by Joseph McCabe (New York: G. P. Putnam's Sons, 1913), 19.

12. Ibid., 101.

13. On Spanish anarchism, see Boyd, Carolyn P., "The Anarchists and Education in Spain, 1868-1909," The Journal of Modern History 48, no. 4, (December 1976).

14. See, Carlos Martínez Assad, "Introducción," Los Lunes Rojos: la educación racionalista en México, 1st. ed., ed. Carlos Martínez Assad (México: Secretaría de Educación Pública. Ediciones El Caballito, 1986), 9-20; José de la Luz Mena, “Tres conferencias del profesor José de la Luz Mena," Los Lunes Rojos, 49. See also Boyd, 22.

15. The most immediate source on Ferrer is his own autobiographical work. See Ferrer, opus cit.; see also Boyd, opus cit.; Murray Bookchin, The Spanish Anarchists: The Heroic Years, 1868-1936 (Oakland: AK Press, 1997). On Ferrer's impact on American education, see Paul Avrich, The Modern School Movement: Anarchism and Education in the United States (Princeton: Princeton University Press, 1980), 69-110.

16. "Fundamentos de la Ley de Institución de las Escuelas Racionalistas," in Los Lunes Rojos, 25, 44.

17. This was also the method for teaching mathematics. See Ferrer, 90.

18. See for example, Ferrer, 73.

19. "Prospecto Plan de la escuela racionalista," in Los Lunes Rojos, 40.

20. This article was originally published in the journal Redención. José Ochoa Lobato, "No aceptamos los concursos escolares," Los Lunes Rojos, 147.

21. Ibid., 148.

22. Ibid., 148.

23. “La voz de la revolución, Mérida, Yucatán, Thursday, August 9th 1917, 35.

24. José de la Luz Mena, La escuela socialista, su desorientación y fracaso. El verdadero derrotero (México, 1941), 401.

25. Elena Torres, "El Quinto tema del Primer Congreso Socialista celebrado en Motul, estado de Yucatán," Los Lunes Rojos, 29.

26. Ibid., 29.

27. de la Luz Mena, La escuela socialista, 18.

28.José de la Luz Mena. “Tres Conferencias del profesor José de la Luz Mena. Tercera Conferencia," in Los Lunes Rojos, 62; see also his defense of activity-based education for this same purpose: José de la Luz Mena, La escuela socialista, 21-22.

29. This is evident in Ferrer's account of the class dynamics of anarchists' schools in Spain. See Ferrer, The Origins and Ideals, 44.

30. I used "supplementarity" here in the sense given to it by Derrida, as suggesting something lacking in the original and that completes it, and, at the same time, something that adds to the original. As we see here, that supplementarity in Mexico oftentimes relates to issues of race and homogeneity. See Jacques Derrida, Of Grammatology, trans. Gayatri Chakravorti Spivak (Baltimore: The John Hopkins University Press, 1998). 


\section{VICTOR J. RODRIGUEZ}

31. “¡Sólo la escuela racionalista educa! Declaración de principios: fundamentos científicos y consecuencias sociales de esta escuela," in Los Lunes Rojos, 147.

32. Ibid., 39.

33. This promise is clearly set forth in the instructions given by the president of Mexico, Venustiano Carranza, in 1914 to a contingent of Mexican teachers about to tour American schools during the years of 1914 and 1915. Eulalia Guzmán participated in these tours, along with over one hundred teachers, in three separate presidential commissions, which traveled to Massachusetts, New York, Philadelphia, Boston, and Washington. See "Instrucciones a la segunda comisión," Boletín de la Secretaría de Educación Pública I, no. 2 (Nov. 1915), 84-85; "Instrucciones a la tercera comisión," in Boletín de la Secretaría de Educación Pública, I no. 2 (Nov. 1915), 85.

34. Guillermo de la Rosa, "Informe de Guillermo de la Rosa," Boletín de la Secretaría de Educación Pública I, no. 2 (Nov. 1915).

35. Eulalia Guzmán, "Informe de Eulalia Guzmán," Boletín de la Secretaría de Educación Pública I, no. 2 (November of 1915), 137.

36. Ibid., 138.

37. Ibid., 138.

38. María Dolores Mendoza, "Informe de María Dolores Mendoza," Boletín de la Secretaría de Educación Pública I, no. 2 (November of 1915), 134-136.

39. For Patri's schools, see James M. Wallace, The Promise of Progressivism: Angelo Patri and Urban Education (New York: Peter Lang Publishing, 2006).

40. Eulalia Guzmán, "Características de la escuela nueva," in Eulalia Guzmán, La escuela nueva o de la acción (México, 1923), 31.

41. Ibid., 37.

42. Ibid., 37.

43. Ibid., 39 .

44. Ibid., 37-39.

45. Eulalia Guzmán, "Características de la escuela nueva," 5.

46. Eulalia Guzmán, "Características de la escuela nueva," 5.

47. Manuel Barranco, "La escuela primaria del futuro," in Educación, 1, no. 1 (Sept 1922), 9.

48. Eulalia Guzmán, "Características de la escuela nueva," 37.

49. Ibid., 38.

50. Ibid., 33-35.

51. Ibid., 38-39.

52. Ibid., 36-37.

53. The ideas of Dewey found their most ardent supporters among unionized teachers in Mexico City during the early 1920s, when the military phase of the Mexican revolution came to an end and the Mexican state-and Mexican society in general-re-organized itself.

54. Segundo congreso nacional de maestros. Reunido en la capital de la República en los días del 15 al 28 del mes de diciembre de 1920. Obra escrita por el Profesor Higinio Vásquez Santa Ana, Srio. del referido Congreso y delegado de los estados de Jalisco, Michoacán y Chiapas (Querétaro, Oficina Tipográfica del gobierno, 1923), 73.

55. Segundo congreso nacional de maestros, 74.

56. See, for example, the dissent of teacher Lopez Ibarra in Segundo congreso nacional de maestros, 56-57.

57. Lisandro Calderón, "El hábito de la acción en la niñez para combatir nuestra apatía racial," Memoria del primer congreso mexicano del niño patrocinado por "El Universal" (México, 1921), 248-249. 
58. José Vasconcelos professed admiration for the American progressive tradition and initially embraced Dewey's approach to education as an important dimension of the modern education project of the revolution. Dewey exemplified for him the ideals of the practical subject as a model to reject the dogmatic subject, the legacy of the Spanish Catholic tradition. Yet after his dismissal from the government, he rejected Dewey as anti-Latin and denounced the state project of the Deweyan escuelas activas, which had just gotten under way in 1923. The critical body of work on Vasconcelos is too numerous to mention. Among notable monographs, see Itzhak Bar-Lewaw M., La Revista “Timón” y José Vasconcelos (México: Casa Edimex, 1971); Mario Aguirre Beltrán, Revista El Maestro, 1921-1923: raíces y vuelos de la propuesta vasconcelista (México: Universidad Pedagógica Nacional, 2002); Joaquín Cárdenas, José Vasconcelos: Caudillo cultural (Oaxaca: Universidad José Vasconcelos de Oaxaca, 2002); Regina Aída Crespo, Itinerarios Intelectuales: Vasconcelos, Lobata y sus proyectos para la nación (México: Universidad Autónoma de México, 2005); Claude Fell, José Vasconcelos. Los años del águila (México: Universidad Nacional Autónoma de México, 1989); and Luis A. Marentes, José Vasconcelos and the Writing of the Mexican Revolution (New York: Twayne Publishers, 2000).

59. Calderón, “El hábito de la acción,” 248-249.

60. Ibid., 248.

61. Ibid., 248. Here, Calderón, for the first time, seems to argue that the much desired "natural" order will not come about just by removing obstacles to liberty, but rather by actively and externally establishing the necessary "common purpose": thus we have two, not one, projects now. And, again, he does affirm Deweyan principles and, at the same time, moves away from them if, as I read him, he suggests that the "element of a common and productive activity" is external to the project.

62. Ibid., 247.

63. Ibid., 246.

64. Calderón, "El hábito de la acción," 246.

65. Ibid., 249.

66. Scholars have identified the "transition to modernity" not so much as a sociological phenomenon, but as a discursive trope, comparative in nature, which organizes and narrates the history of the nation as moving towards self-consciousness and thus modernity. See, for example, Dipesh Chakrabarti, Provincializing Europe: Postcolonial Thought and Historical Difference (Princeton: Princeton University Press, 2000).

67. See Víctor Arreguine, En que consiste la superioridad de los latinos sobre los anglosajones (Buenos Aires, 1900); Edmond Demolins, A quoi tient la superiorité des anglo-saxons (Paris: Firmin-Didot et cie, 1898); Edmond Desmolins, A science sociale depuis F. Le Play, 1882-1905. Classification sociale resultant des observations faites d'après la methode de la science sociale par Edmond Desmolines (Paris, 1905). See also the seminal Latin American nationalist essay Ariel, José Enrique Rodó, Ariel. 2nd. Ed. (Madrid: Cátedra, Letras Hispánicas, 2003.For a scholarly analysis of this issue see, Castro Belén, "Introducción," in Ariel, opus cit., Detlef Müller, Fritz Ringer, and Brian Simon, editors, The Rise of the Modern Educational System: Structural Change and Social Reproduction 1870-1920 (Cambridge: Cambridge University Press, 1990).

68. Lima, Salvador M. and Marcelino Rentería. "La escuela nueva de la acción: los errores de la vieja escuela," Educación, vol. 2, no. 4, (August 1923), 243.

69. "Bases para la organización de la escuela primaria conforme al principio de la acción,” Educación 3, no. 1 (Jan. 1924), 2, 6. 


\section{ViCTOR J. RODRIGUEZ}

70. Manuel Barranco, La escuela del futuro, Educación 1, no. 1 (October of 1922), 62.

71. Marcelino M. Lima and Marcelino Rentería. "La escuela de la acción: los errores de la vieja escuela," Educación 2, no. 4, (Jan, Aug 1923), 242.

72. Lucio Tapia, “Orientaciones de la escuela popular," Educación 1, no. 5 \& 6 (Jan., Feb. 1922), 569.

73. José Vasconcelos, La Raza Cósmica, translated and annotated by Dider T. Jaén (Baltimore: The John Hopkins University Press, 1979), 57.

74. Bases para la organización de la escuela, 6.

75. Lucio Tapia, "Caracteres Sociológicos de la raza indígena de México e institutos docentes que son necesarios para lograr su redención,” Educación 2, no. 4 (Aug, 1923), 273.

76. Ibid., 276.

77. Bases para la organización de la escuela, 2.

78. José María Bonilla, "Nuevas orientaciones a la educación nacional," Educación 1, no. 2 (Sept. 1922).

79. Caso, Antonio, "Problemas Nacionales," Antología filosófica, (México, Ediciones de la Universidad Autónoma, México, 1957), 214.

80. Vasconcelos, La Raza Cósmica, 57.

81. Vasconcelos, José, "Discurso inaugural del edificio de la secretaría," Obras Completas, vol. II, 800 .

82. Emilio Rabasa, El juicio constitucional: orígenes, teoría y extensión (Paris: Ch. Bouret, 1919), 52. For an excellent discussion of Rabasa's contribution to Mexican intellectual life, see Charles A. Hale, "The Civil Law Tradition and Constitutionalism in Twentieth-Century Mexico: The Legacy of Emilio Rabasa," Law and History Review, vol. 18, no. 2, (Summer 2000).

83. Tapia, Caracteres Sociológicos, 274.

84. Ibid., 273.

85. Bases para la organización de la escuela, 7.

86. Ibid., 2.

87. For Alvarado's early life see, Antonio Pompa y Pompa, "Prólogo," Antología Ideológica, opus cit.

88. Alvarado, "El Problema de la educación," 116.

89. Alvarado, "El Problema de la educación,"116.

90. Ibid., 103.

91. Ley de educación primaria (Mérida: Departamento de Educación Pública de Yucatán, 1918), 3. See also, El Primer Congreso Feminista de Yucatán, convocado por el C. gobernador y comandante militar del estado, Gral. Don Salvador Alvarado (Mérida: Talleres Tipográficos del "Ateneo Peninsular," 1916), 89-97.

92. Salvador Alvarado, "Carta al pueblo de Yucatán publicada en la Voz de la Revolución, 5 de mayo de 1916, aniversario de Gloria para la patria mexicana," La cuestión de la tierra, 1915-1917. Colección de folletos para la historia de la Revolución Mexicana, dirigida por Jesús Silva Herzog (México: Instituto Mexicana de Investigaciones Económicas, 1962), 189-190.

93. Jean-Pierre Bastian, Protestantismo y sociedad en México (México: CUPSA (Casa Unidad de Publicaciones, 1983), 166.

94. Richard Hofstadter, Anti-Intellectualism in American Life (New York: Vintage Books, 1962, 1963), 367.

95. EW5:96.

96. Alvarado, "El Problema de la educación,"102-103.

97. LW11:294. 
Radical Dewey: Deweyan Pedagogy in Mexico, 1915-1923 97

98. LW11:62.

99. Hofstadter, 368.

100. Larry Hickman, John Dewey's Pragmatic Technology (Bloomington: Indiana University Press, 1990), 11.

101. Larry Hickman, “Dewey's Theory of Inquiry," Reading Dewey: Interpretations for a Postmodern Generation (Bloomington: Indiana University Press 1998), , 179.

102. LW1:71.

103. Ibid., 71.

104. Hickman, John Dewey's Pragmatic Technology, 41.

105. Ibid., 15.

Victor J. Rodriguez is an Assistant Professor of History at United International College, a liberal-arts college in mainland China.

E-mail: analytical.vic@gmail.com 
